\title{
Microbial Air Quality in Port Harcourt, Nigeria
}

\author{
Kome Otokunefor* and Hillary Mabel Victor
}

\author{
Department of Microbiology, Faculty of Science, University of Port Harcourt, \\ P.M.B. 5323, Port Harcourt, Nigeria \\ *Corresponding author:
}

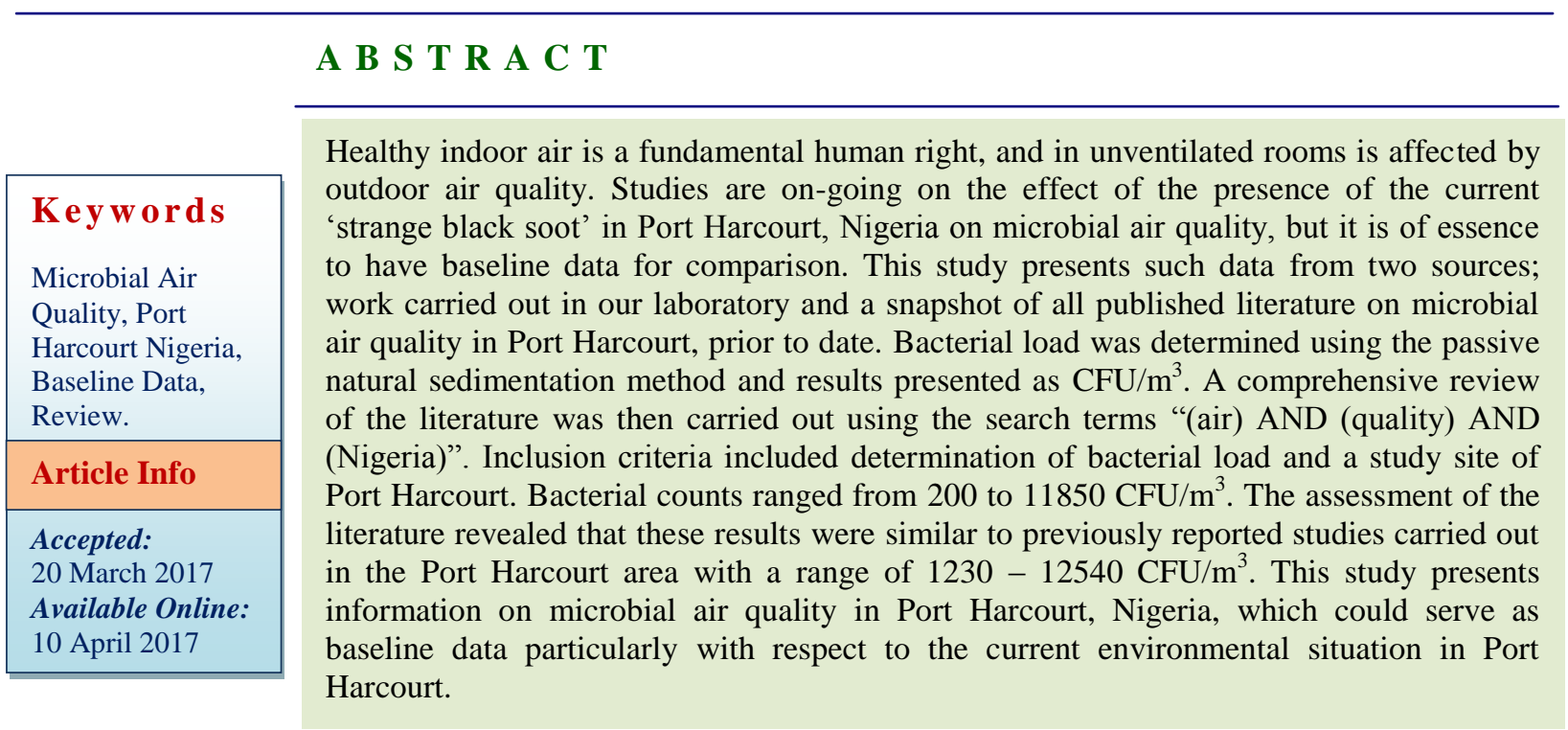

\section{Introduction}

Numerous studies have been carried out worldwide assessing indoor microbiological air quality, pointing at the important role air quality plays in impacting the general health and well being of humans as a whole. A World Health document outlining the WHO guidelines for indoor air quality, describes healthy indoor air as a fundamental human right. This is particularly important considering that a significant number of people have been reported to spend the majority of their time (between $80 \%$ and 90\%) indoors (Hospodsky et al., 2012; Hayleeyesus and Manaye, 2014). Currently, though no single international standard exists as a guide for bacterial contamination of indoor air, several recommendations have been made. A WHO publication asserts that environments with a greater than $1000 \mathrm{CFU} / \mathrm{m}^{3}$ microbial load should be considered contaminated (WHO, 2009). Most other reports have set thresholds ranging from 500 to $1000 \mathrm{CFU} / \mathrm{m}^{3}$ as acceptable (Nevalainen and Morawska, 2009; Borrego et al., 2012; Naruka and Gaur, 2013; Kabir et al., 2016).

The quality of indoor air may be affected by several factors. One of such factors is the influence of the external environment, with 
reports that in a well-ventilated room, the indoor air quality is similar to that of the outdoor air quality (Meadow et al., 2014). Since November 2016, Port Harcourt has been affected by a 'strange black soot' of relatively unknown source (The Guardian, 2017). Port Harcourt, the capital city of Rivers State, Nigeria, is part of the oil producing Niger Delta region of the country. Several speculations on the source of the soot have pointed at illegal refineries and asphalt burning by asphalt firms. The presence of the black soot has been suspected of being linked with respiratory tract infections. There have however been no documented confirmatory reports so far. One important facet of air quality is the level and composition of airborne bacterial load. And no reports, speculative or otherwise, have so far made mention of the effect of the current event in Port Harcourt on bacteriological air quality.

Prior to this time, several studies have been carried out to ascertain both microbial load and composition to provide a picture of air quality in different locations in Port Harcourt. One such study was carried out in our lab. This article therefore sets out to present the results of the effect of human activity on microbial load in a University classroom environment prior to the current 2017 environmental problems, as well as provide a summary of all the published work done to date on microbial air quality in Port Harcourt, in a bid to provide a benchmark for subsequent comparisons.

\section{Materials and Methods}

\section{Determination of bacterial load 'pre-black soot'}

Determination of bacterial load was carried out between October and November 2015. Air sampling was carried out using the passive natural sedimentation method as previously described (Napoli et al., 2012). Sampling was carried out in duplicates, at two different time points, before the beginning of the days' activities ("at rest") and after the days" activities, on seven lecture halls at the University of Port Harcourt, Faculty of Science complex. Total bacterial count was determined using nutrient agar (NA). Following this, $\mathrm{CFU} / \mathrm{m}^{3}$ determined using the Omeliansky equation (Borrego et al., 2012) $\mathrm{N}$ $=5 \mathrm{a} \times 10^{4}(\mathrm{bt})^{-1}$.

Where: $\mathrm{N}=$ colony forming unit per cubic meter of air $\left(\mathrm{CFU} / \mathrm{m}^{3}\right) \mathrm{a}=$ number of colonies per Petri dish, $b=$ dish square centimeter, $t=$ exposure time (min).

\section{Review Protocol/Search Criteria}

To obtain a comprehensive review of published literature, a direct PUBMED search was carried out using the following search terms "(air) AND (quality) AND (Nigeria)". Subsequent search of Google Scholar was then carried out using "the same or similar" search terms. Papers were deemed eligible for inclusion only if the study involved determining at least the bacterial load and were carried out in Port Harcourt, Rivers State.

\section{Results and Discussion}

\section{Air Sampling}

Bacterial counts varied between sampling sites (Fig. 1), with counts ranging from 200 to $8250 \mathrm{CFU} / \mathrm{m}^{3}$ in the morning and $2650-$ $11850 \mathrm{CFU} / \mathrm{m}^{3}$ in the evening (average of 4019 and $7907 \mathrm{CFU} / \mathrm{m}^{3}$ respectively).All sites had higher levels of bacterial load in the evening, than in the morning. The levels of variation however differed (Table 1). Three sites had a less than $15 \%$ increase in total bacterial load, while for two sites, the increase in bacterial load was greater than $1000 \%$. 


\section{Literature review/summary of literature}

A PUBMED and Google Scholar search for articles on microbial air quality in Port Harcourt found five articles published between 2012 and 2016. Majority (4/5) of these studies assayed indoor air quality. These studies all used a similar sampling method, the settle plate or passive natural sedimentation method. They however differed in their mode of result presentation. Of the 5 studies, only 2 represented the results of their study as $\mathrm{CFU} / \mathrm{m}^{3}$ (Udochukwu et al., 2015; Emuren and Ordinioha, 2016).These studies did not however describe how these values were obtained, and reported values ranging from $5.33-227.33 \mathrm{CFU} / \mathrm{m}^{3}$. Two other studies (Wemedo et al., 2012; Agbagwa and Onyeamachi, 2014) presented their results as CFU/30min and simply as 'no of colonies'. Conversion of these values to $\mathrm{CFU} / \mathrm{m}^{3}$ based on the Omeliansky formula (Borrego et al., 2012) showed a wide variation in microbial load present, with a rangeof $1230-12540$ $\mathrm{CFU} / \mathrm{m}^{3}$. The final study (Mbakwem-Aniebo et al., 2016) presented results as $\mathrm{CFU} / \mathrm{m} 2 / \mathrm{h}$, with values ranging from $75-4710$.

With each human being inhaling $14 \mathrm{~m}^{3}$ of air per day on the average (Kabir et al., 2016), the potential impact air quality has on the quality of human life cannot be overemphasized. The microbial analysis of indoor air quality carried out in this study revealed a count range of $200-11850 \mathrm{CFU} / \mathrm{m}^{3}$ and these were generally (12/14) above the recommended acceptable standards. This range was however similar to two previously published reports on air quality in Port Harcourt (Wemedo et al., 2012; Agbagwa and Onyeamachi, 2014), which reported ranges of 1230 - 6660 and $1500-12540$ respectively.

Table.1 Level of variation in bacterial load

\begin{tabular}{lccccccc}
\hline Site ID & A & B & C & D & E & F & G \\
\hline \% Level of & 78 & 76.9 & 13.3 & 3.9 & 1225 & 2288 & 1.3 \\
Variation & & & & & & & \\
\hline
\end{tabular}

Fig.1 Total bacterial count on nutrient agar (CFU/m3)

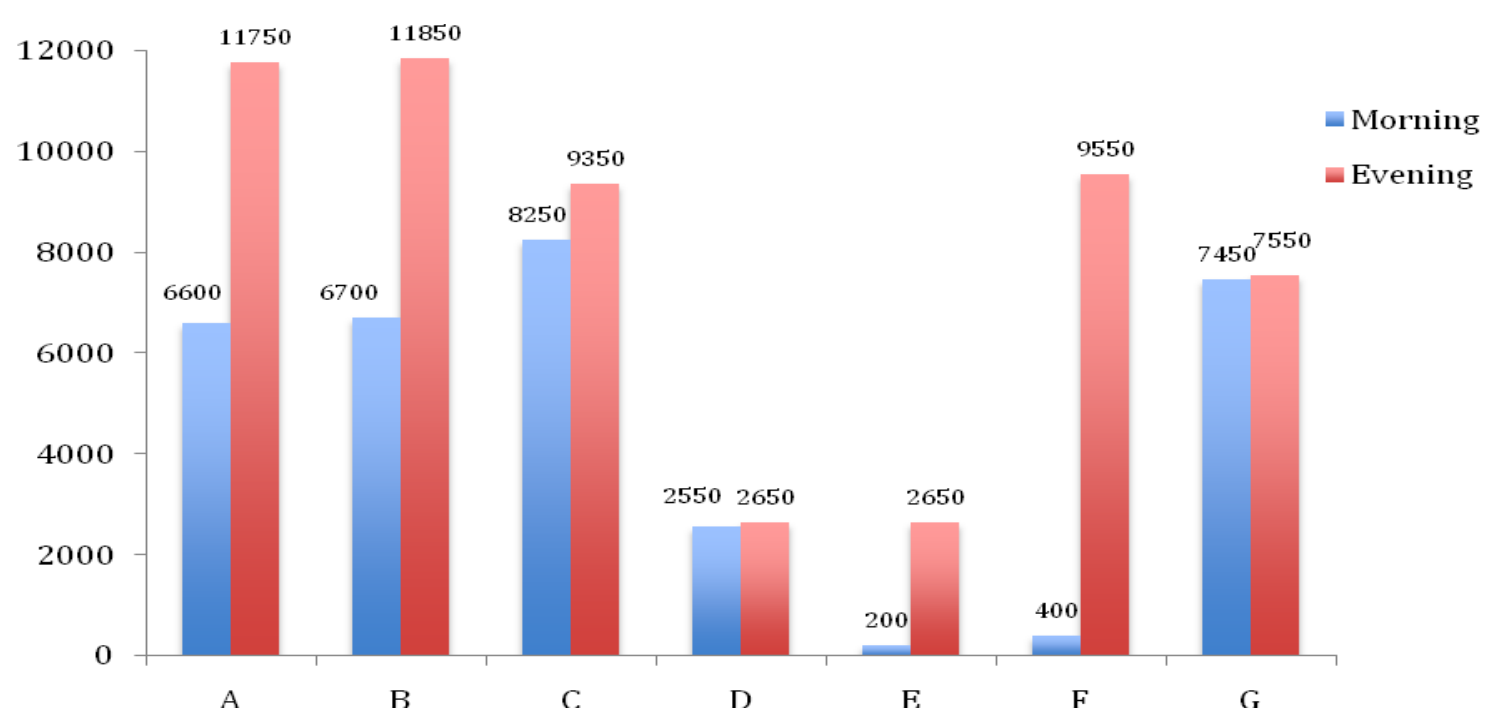


Also, these ranges were similar to those of several studies carried out in Ethiopia, which noted microbial loads with ranges of 117 7284, 397 - 2595, 511 - 9960 and $3106-$ 9733 (Kabir et al., 2016; Hayleeyesus and Manaye, 2014; Hayleeyesus et al., 2015; Fekadu and Getachewu, 2015).

These studies noted a variation in microbial load based on sampling location (i.e. indoor or outdoor), function of the indoor environments and month of the year. A similar study carried out in Poland (Fraczek and Gorny, 2011), also noted a range of 21 6223. All these reports however differed from some reports from the rest of Nigeria, which noted low microbial loads with ranges such as $42-100,422-1386$ and $45-1125 \mathrm{CFU} / \mathrm{m}^{3}$ (Makut et al., 2014; Ambrose et al., 2015; Awosika et al., 2012). One common observation of the various studies, was the effect of human activity on microbial load. This trend was also observed in our study with higher microbial loads observed at the end of the day (Figure 1), possibly due to human activity.

The analysis of current literature on microbial air quality in Port Harcourt yielded data that could serve as a baseline for further comparison. This data was comparable with previously published literature as noted in the preceding paragraph. Additionally though, this assessment of the literature revealed an immediate need for standardization and clear representation of methodology, despite the fact that 5 different articles reported on microbial air quality in Port Harcourt, Rivers State, Nigeria, data comparison could only be clearly made from two papers due to a lack of standardized methodology. While all 5 studies made use of the passive sampling methodology, variations existed in the representation of the results obtained following the passive sampling. Various methods are widely employed, with results presented as $\mathrm{CFU} / \mathrm{m}^{3}, \mathrm{CFU} / \mathrm{m} 2 / \mathrm{h}, \mathrm{CFU} / 30 \mathrm{~min}$ and 'number of colonies'. To aid widespread comparison therefore, it is expedient for the scientific community to come up with standard data reporting with regards to microbial air quality reporting, and lay out guidelines advising on specific methodology to be employed under specific conditions.

In conclusion, though our study presents baseline data, which is of essence for future comparisons especially with the current environmental situation in Port Harcourt, Nigeria, it also highlights several limitations that could be addressed by future studies.

\section{References}

Agbagwa, O.E., Onyemaechi, S.A. 2014. Microbiological quality of indoor air of a general hospital and a health center in Rivers State Nigeria. Int. J. Curr. Microbiol. Appl. Sci., 3(12): 424 - 431.

Ambrose, I., Nweke, C.O., Umeh, S.C.I., Braide, W. 2015. Prevalence of bioaerosols in the outdoor air environment in Uyo Urban, Akwa Ibom state, Nigeria. Int. Res. J. Microbiol., 6(2): 012 - 019.

Awosika, S.A., Olajubu, F.A., Amusa, N.A. 2012. Microbiological assessment of indoor air of a teaching hospital in Nigeria. Asian Pacific J. Trop. Biomed., 2(6): $465-468$.

Borrego, S., Lavin, P., Perdomo, I., Gómez de Saravia, S., Guiamet, P. 2012. Determination of indoor air quality in archives and biodeterioration of the documentary heritage. ISRN Microbiol., 30.

Emuren, K., Ordinioha, B. 2016. Microbiological assessment of indoor air quality at different sites of a tertiary hospital in South-South Nigeria. Port Harcourt Med. J., 10(2): 79 - 84.

Fekadu, S., Getachewu, B. 2015. Microbiological assessment of indoor air of Teaching hospital wards: a case of Jimma University specialized hospital. 
Ethiopian J. Health Sci., 25(2): 117 122.

Hayleeyesus, S.F., Manaye, A.M. 2014. Microbiological quality of indoor air in university libraries. Asian Pacific J. Trop. Biomed., 31(4): S312 - S317.

Hayleeyesus, S.F., Ejeso, A., Derseh, F.A. 2015. Quantitative assessment of bioaerosols contamination in indoor air of University dormitory rooms. Int. $J$. Health Sci., 9(3): 249 - 256.

Kabir, M.S., Mridha, F., Islam, S., Shorifujjaman, M. 2016. Microbiological pollutants in air and antibiotic resistance profile of some bacterial isolates. Jahangirnagar University, J. Biol. Sci., 5(1): $47-56$.

Hospodsky, D., Qian, J., Nazaroff, W.W., Yamamoto, N., Bibby, K., RismaniYazdi, H., Peccia, J. 2012. Human occupancy as a source of indoor airborne bacteria. PloS one, 7(4): e34867.

Makut, M.D., Nyam, M.A., Shehu, L., Anzaku, S.J. 2014. A survey of the microflora of the outdoor air environment of Keffi Metropolis, Nasarawa State, Nigeria. African J. Microbiol. Res., 8(27): 2650 2655.

Mbakwem-Aniebo, C., Stanley, H.O., Onwukwe, C.D. 2016. Assessment of the indoor air quality of Majors' biological laboratories in Ofirima comples, University of Port-Harcourt, Nigeria. $J$. Petroleum and Environ. Biotechnol., 7(4): 285.

Meadow, J.F., Altrichter, A.E., Kembel, S.W., Kline, J., Mhuireach, G., Moriyama, M., Northcutt, D., O'connor, T.K., Womack,
A.M., Brown, G.Z., Green, J.L. Indoor airborne bacterial communities are influenced by ventilation, occupancy, and outdoor air source. Indoor Air, 24(1): 4148.

Napoli, C., Marcotrigiano, V., Montagna, M.T. 2012. Air sampling procedures to evaluate microbial contamination: a comparison between active and passive methods in operating theatres. $B M C$ Public Health, 12(1): 594.

Naruka, K., Gaur, J. 2013. Microbial air contamination in a school. Int. J. Curr. Microbiol. Appl. Sci., 2(12): $404-410$.

Nevalainen, A., Morawaska, L. 2009. Biological agents in indoor environments; assessment of health risks. Work conducted by a WHO Expert Group between 2000-2003.

The Guardian 'Strange black soot' causes anxiety in Port Harcourt 2017. https://guardian.ng/news/strange-blacksoot-causes-anxiety-in-port-harcourt/ Assessed $1^{\text {st }}$ March 2017.

Udochukwu, U., Omeje, F.I., Anulude, O.C., Ogechi, O.K. 2015. Microbiome of enclosed air in selected dormitories in University of Port Harcourt. American J. Res. Coтmu., 3(5): 217 - 224.

Wemedo, S.A., Ede, P.N., Chuku, A. 2012. Interaction between building design and indoor airborne microbial load in Nigeria. Asian J. Biol. Sci., 5(4): 183 - 191.

World Health Organisation. 2009. WHO guidelines for indoor air quality: dampness and mould. WHO Copenhagen, Denmark.

\section{How to cite this article:}

Kome Otokunefor and Hillary Mabel Victor. 2017. Microbial Air Quality in Port Harcourt, Nigeria. Int.J.Curr.Microbiol.App.Sci. 6(4): 2293-2297. doi: https://doi.org/10.20546/ijcmas.2017.604.267 